\title{
Customer Satisfaction towards Product and Service Quality of Housing Developers in West Sumatra Indonesia
}

\author{
Difana Meilani ${ }^{\#}$, Prima Fithri ${ }^{\#}$, Putri Yanna Reista ${ }^{\#}$ \\ ${ }^{\#}$ Department of Industrial Engineering, Faculty of Engineering, Andalas University, \\ Kampus Limau Manis, Pauh, Padang 25163, West Sumatera, Indonesia \\ E-mail:difana@eng.unand.ac.id,primafithri@eng.unand.ac.id,yannareista@gmail.com
}

\begin{abstract}
This research focuses on the product quality and service rendered quality. It also studies the priority of items attributes that should be increased by the housing developers for improving customers' satisfaction and facing competition with other housing developers. The improvement of service quality is carried out through adopting the proposed improvements. Questionnaires which are for measuring customers' satisfaction and questionnaire and desired condition are carried out. The answers are then analyzed statistically. Methods of IPA and HOQ are applied to identify the formulation of the problem and to correlate the customers' desired to technology capabilities of the company. From the analysis, by using IPA, 76\% in the level of satisfaction for the quality of product and $78 \%$ in the level of service satisfaction. While, by using HOQ, the improvement focuses on regular renovation, public facilities, foundry street and road, and drainage cleaning. Furthermore, coordination among sub-contractors who handling the construction of houses, adding hours of office operation, and providing feedback mechanism for suggestions must get attention. This research is useful for housing developers who are in developing country and needs improvement for the strategy of the housing sale from the residents' point of view. The value of this research is to describe the resident's priority of items attributes of the house that they bought and services that they received from the developers. The developers should consider the factors that increased customers' satisfaction and hopefully it can increase the house sales.
\end{abstract}

Keywords - housing developer; customer satisfaction; service standards; Importance Performance Analysis (IPA); House of Quality (HOQ); Quality Function Deployment (QFD); service quality; Indonesia; service satisfaction level; assessment

\section{INTRODUCTION}

A house is a basic need of human being. It is as important as food and clothes. To build or buy a house needs time and money. Furthermore, the maintenance of the land, the ownership, the housing structure, feasibility tests and trials, and building permits are also considerable factors.

Carling emphasized that supported housing aims to help individuals "choose, get, and keep" the type of housing that they want [1]. Therefore, many housing developers appear and provide assistance for people who need houses. While, Indonesia as a developing economies country must consider the environment, traffic, and housing structure which is written in the housing policy 2011.

On 30 September 2009, a province in Indonesia called West Sumatra has experienced an $\mathrm{M}_{\mathrm{w}}$ 7,6 earthquake which caused people lost their houses. Since that time, the numbers of housing developers increase sharply. It can be seen from the high numbers construction of schools, hotels, hospitals, entertainment venues, and houses. Furthermore, Iftekhar stated that to make the growth of property development more successful, the factors that influence the industry are context, the scale of programmed, budget, political goodwill, and cooperation of communities [2].

Padang which is the capital city of West Sumatra located $0.9471^{\circ} \mathrm{S}, 100.4172^{\circ} \mathrm{E}$ got the highest houses damage during the earthquake. It is shown in Fig. 1.

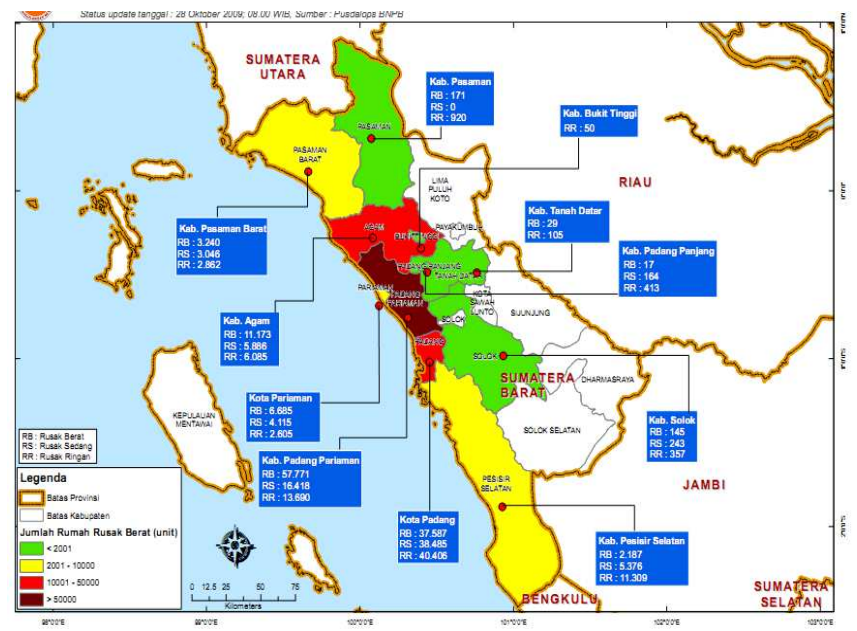

Fig. 1 Number of damage house map in West Sumatra Province [3] 
From Fig. 1, it is shown that the damaged houses in Padang are 120.478 housing units which are categorized as heavy damaged 37.587 units, damaged 38.485 units, and lightly damaged 40.406. Moreover, Padang has been stated as an area prone to the tsunami disaster. It means disaster can come anytime. Therefore, the government divided the areas of Padang into the danger zone and safe zone. This has prompted people especially those whose houses destroyed by the earthquake to buy new houses in the safe zone, rather than repairing the old ones.

Therefore, various types of houses are offered by the housing developers. They compete with each other in providing compete for facilities and also in the building location such as the city center and ridgeline which are in the safe zone. Besides that, building condition is also an important issue in all over the world to enhance safety [4]. The business in housing rises quickly. It can be seen from Fig. 2.

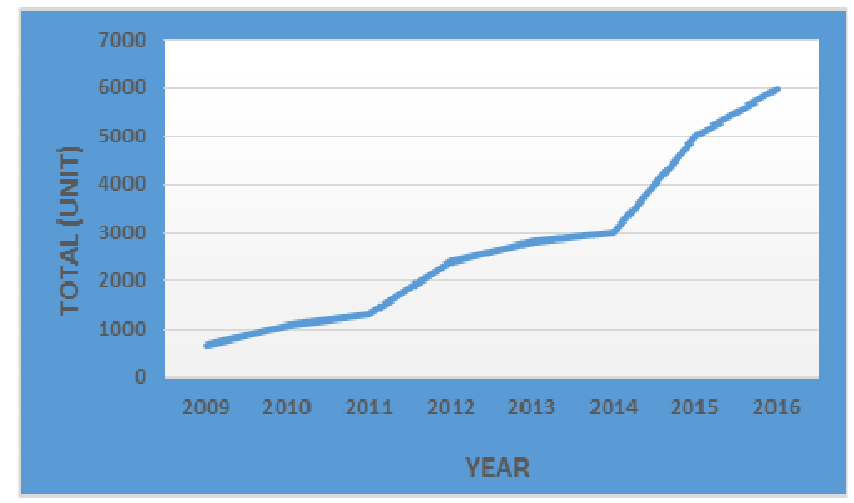

Fig. 2 House development progress in Padang city

It shows that between 2009 and 2016 the numbers of house construction increased sharply together with the numbers of the developers. In 2011, there were only 50 housing developer's companies, but now there are 101 companies listed in REI (Real Estate Indonesia).

With the increasing number of a company engaged in the real estate and the accompanied by a wide range of construction and type of house, it is getting easier get residences. Therefore, potential customers must be keen in selecting a developer. The credibility of a developer is momentous to reck since it affected the offering product. The better the credibility means, the better quality.

PT Hati Prima Griya Elok is a housing developer in Padang which has been established since 1995, and its first house constructed, in 2006, offered cluster and non-cluster types of housing. Griya Elok Residence and Griya Elok Arai Pinang were their housing developments. Based on the presurvey, $80 \%$ of the housing residents are not satisfied with the performance of the company in providing the products and services. This condition will cause a reduced number of the sale. Therefore, housing developers need to standardize in fulfill customers' needs. Furthermore, the quality of the house and services also have an important role in the housing project since it relates to the house buyer's satisfaction and also private developers profit and market share [5]-[10]

Hansemark \& Albinsson, Kotler, and Hoyer \& MacInnis stated that the housing companies need to know the attributes that can increase customers' satisfaction regarding the fulfillment of some desires, needs or goals [11]-[14]. Furthermore, suggestions for the improvement of the company are also needed. By knowing the right suggestions and implementing them, evaluation can be carried out. They summarized that focusing on the right attributes and the right suggestions will give positive changes for the development of this company and in facing the competition from other housing developers.

Meanwhile, there are numerous contributions in the literature that relate to customers' satisfaction with concepts such as customer loyalty, repetition of orders, the word-ofmouth effect and the increase in profitability [15]-[17]. There are also numerous empirical studies that have found a positive relationship between customer satisfaction and business results [15], [18]. In order to understand the customers and, by extension, the markets in which the companies are involved, it is essential to listen to the customers' needs and to compile and study quantitative and qualitative data on the extent of their satisfaction.

Jacob et al. suggested that some companies or developers have improved such an attribute only to experience that overall satisfaction did not increase as one would expect from the importance performance map [19]. This suggests that the assumption of independence between importance and performance might be flawed. It has been observed in several studies within the field of customers' satisfaction that when companies deliberately change the performance of an attribute the importance of this attribute in relation to overall customer satisfaction is changed [20]-[24].

Companies will always try to compare their product with their competitors. In industry, QFD is a technique of product development to translate customer requirements for product development activities and services [25], [26]. They will also try to examine any customers' satisfaction information that happens to be available. Unfortunately, much of this information is often incomplete. By contrast, Quality Function Development (QFD) uses matrix format to capture a number of issues that are important to the planning process. A key technique of QFD is House of Quality (HOQ) [27]. HOQ uses a planning matrix to capture what the customer wants and how a company is going to meet those requirements.

Based on the discussion above, this study addresses the following questions:

1. How is the quality of satisfaction of the products and services provided by the developer?

2. What are the items priority improvements of housing developers in product quality and service quality?

3. What are the proposed improvement priorities of housing developers that can be given based on the House of Quality (HOQ) method?

\section{MATERIAL AND METHOD}

A preliminary survey was conducted to collect information regarding the profile of the housing developer and also to learn about the existing work processes of the developer. By interviewing the company employees, it is known that PT Hati Prima Griya Elok has operated since 1995 and it now has 16 permanent and contract employees. 
PT Hati Prima Griya Elok started the construction of their first housing project in 2006 in Padang, Indonesia and finished in 2008. The houses were a single type of housetype 40/120. The second housing project started in October 2008 and 2011. Now, in their projects, the company handles a variety of housing types.

In this research, a survey by using a questionnaire was done. The questionnaire was given to 30 residents for the purpose of validation, and also to 132 residents. The results were processed using the IPA and HOQ.

Furthermore, the interview was also done by doing a direct observation of the residents of PT. Hati Prima Griya Elok. Many residents complained about the company's performance, especially in the provision of public facilities, such as the unavailability of prayer room and the damage along the residential streets. In addition, they also complain regarding irrigation system which is not good and usually causes flooding during heavy rain.

Respondents in this research were residents who have purchased and occupied the houses of the second construction project of PT. Hati Prima Griya Elok. From the data that was collected, during the second construction project, the company had sold 132 houses. It is concluded that the size of the population of the respondents of this research is 132 residents- one resident for one house.

The next step was developing the instrument for collecting the data. The instrument was a questionnaire divided into two parts. Part one was used to identifying the respondents, and part two was used to measure the variables.

In this research, the Likert Scale was used to measure customers' satisfaction towards product and service qualities or perceived condition. It consists of five levels- Strongly Agree (SA), Agree (A), Doubt (D), Disagree (DA) and Strongly Disagree (SDA) was applied. The related weights for the scale are 5, 4, 3, 2, 1, respectively. Furthermore, for determining the interest rate for the service and product or desired condition, the levels are Very Important (VI), Important (I), Fair (F), Less Important (LI), and Not Important(NI) with the same weight as how the Likert is weighted. The question items were selected based on an interview and survey conducted with the developer and residents of the houses.

After collecting the data, the next step was to analyze the data using statistical methods to build the House of Quality (HOQ). The objectives of the analysis were to find the level of customers' satisfaction with the product and services. In order to assure the reliability and validity of the instrument, a pilot study was conducted. In the pilot study, questionnaires were distributed to 30 respondents.

The results of the pilot study showed that all questions used in the questionnaires to measure the variables are reliable and valid. In the pilot study, the reliability and validity criteria were made according to Zikmund et al. [28]. The variables are said to be reliable if the value of Alpha Cronbach > 0.6 and it is valid because the output that is shown from software SPSS 16.0 is above $\mathrm{r}_{\text {table, }}, 0,188$.

\section{RESULTS AND DISCUSSION}

In line with the research questions, the finding and results are presented in two parts: Importance Performance Analysis and House of Quality (HOQ). The analysis determined the validity and reliability of the factors from the data gathered using the questionnaires which were given to 132 residents. This research shows that the data and items collected for measuring customers' satisfaction toward product and service quality for the perceived condition, and desired condition were valid and reliable. This data was then being processed by applying IPA and HOQ method.

\section{A. Importance Performance Analysis}

The steps used in applying the IPA method are as follows:

1) Determine the Level of Compatibility between the Interest Rate and the Level of Satisfaction by Comparing Scores with the Score of Interest: Processing the data using Importance Performance Analysis (IPA) consists of calculating the level of suitability and defines the results in the Cartesian diagram.

The first step is to measure the level of suitability. Level of suitability is the ratio between the perceived condition score with the score level desired condition. The levels of suitability are divided into three level; $0-65 \%$ as unsatisfied; $66 \%-100 \%$ as less satisfied; and more than $100 \%$ as very satisfied. The calculation of the level of suitability between perceived and desired conditions for product quality has results that from 16 questions; 5 questions are unsatisfied and 11 questions are less satisfied. Furthermore, for service quality from 14 questions; 2 questions are unsatisfied, 6 questions are less satisfied, and 6 questions are satisfied. The average level of suitability between perceived and desired conditions for service quality is $78 \%$ and for product quality is $76 \%$.

2) Calculate the Average for each Attribute that is Perceived by the Respondents: For each question, the average values of customers' interest and satisfaction were computed. Those values were then plotted in a Cartesian diagram. The horizontal axis of the diagram was the average of the level of satisfaction, and its vertical axis was the average of the level of interest. The diagram was then divided into 4 quadrants. Analyses were focused on the quadrant I and III which represented the highest level of interest and the lowest level of satisfaction. The scores were plotted into four quadrants, and each quadrant covers related sub-indicators as described in Fig. 3 for product quality and Fig. 4 for service quality. Sub-indicators highlighted in the quadrant I and III were the greatest priority for improvement. The sub-indicators in the quadrant I and III for product quality were building quality, location factors, facilities and infrastructure and for service quality, the sub-indicators were reliability, assurance, and responsiveness. 


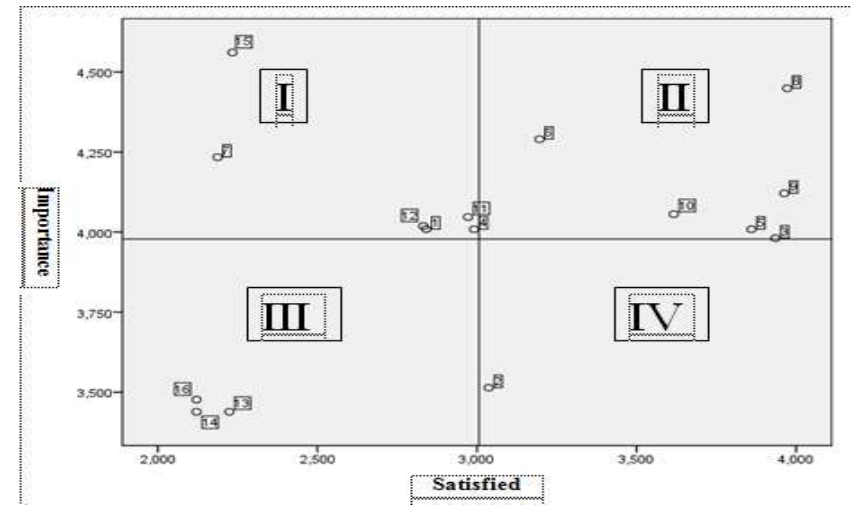

Fig. 3 Cartesian diagram of product quality

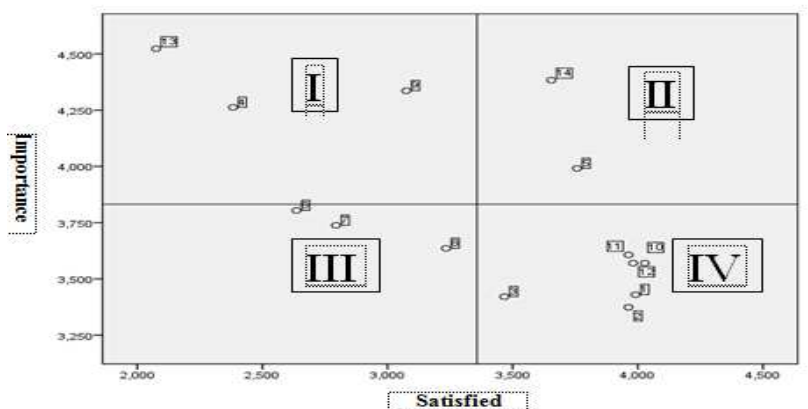

Fig. 4 Cartesian diagram for service quality

\section{B. House of Quality}

The steps used in applying the HOQ method are as follows:

1) Voices of Customers: Sub indicators obtained in the quadrant I and III of Cartesian diagram for product and service quality are applied to build the House of Quality. The sub-indicators will be transformed into the voice of customers.

2) Technical Characteristics: The customers' needs are responded technically by the housing developers to increase the satisfaction level of customers. The technical characteristics are defined based on the interview conducted with the company's architects. The next step is to correlate the customers' voices and the technical characteristics in the form of a correlation matrix.

3) Technical Characteristics Priority: Sometimes, it is almost difficult to accommodate all the technical characteristics at the same time, and therefore it is ranked based on its priority. The process of ordering the priority is calculated by multiplying the interest rate of the costumers with the value of the matrix of relationship (0,1,3 and 9). The result is shown in Table 1.

TABLE I

THE SCORE OF TECHNICAL CHARACTERISTICS PRIORITY

\begin{tabular}{|c|c|c|c|}
\hline No & Technical Characteristic & $\begin{array}{c}\text { Voice of } \\
\text { Costumer (VOC) }\end{array}$ & $\begin{array}{l}\text { Priority } \\
\text { Percentage }\end{array}$ \\
\hline 1 & $\begin{array}{l}\text { Provide free renovations for a month after } \\
\text { the handover of the house key }\end{array}$ & Warrants in a specified period to prospective residents & 21.54 \\
\hline \multirow[t]{2}{*}{2} & \multirow{2}{*}{$\begin{array}{l}\text { Carry out routine maintenance and } \\
\text { cleaning of drainage }\end{array}$} & $\begin{array}{l}\text { Locations of the houses were not flooded in the rainy } \\
\text { weather }\end{array}$ & \multirow{2}{*}{19.92} \\
\hline & & Rain water disposal facilities / drainage are available & \\
\hline 3 & $\begin{array}{l}\text { foundry street and road improvements on a } \\
\text { regular basis }\end{array}$ & $\begin{array}{l}\text { Circumstances surrounding the houses are smooth } \\
\text { and are not damaged }\end{array}$ & 19.59 \\
\hline \multirow[b]{2}{*}{4} & \multirow{2}{*}{$\begin{array}{l}\text { Coordinate more } \\
\text { intensively to the sub-contractor who } \\
\text { handles the } \\
\text { construction of the } \\
\text { houses }\end{array}$} & $\begin{array}{l}\text { The buildings were not damaged during the } \\
\text { earthquake occurred }\end{array}$ & \multirow[b]{2}{*}{19.68} \\
\hline & & The roofs of the houses do not easily leak & \\
\hline \multirow[t]{2}{*}{5} & \multirow{2}{*}{$\begin{array}{l}\text { Provide forms for critiques and } \\
\text { suggestions }\end{array}$} & $\begin{array}{l}\text { The ease of communication between the company and } \\
\text { the consumers }\end{array}$ & \multirow[t]{2}{*}{12.20} \\
\hline & & Employee understanding of consumers' desires & \\
\hline \multirow{3}{*}{6} & \multirow{3}{*}{$\begin{array}{l}\text { Adding office hours of operation } \\
\text { especially on Saturday }\end{array}$} & $\begin{array}{l}\text { Employees attend office on holidays to help } \\
\text { answering customers' Questions }\end{array}$ & \multirow{3}{*}{4.99} \\
\hline & & Responsive in handling all consumers complaints & \\
\hline & & $\begin{array}{l}\text { The ease of Communication between the company } \\
\text { and the consumers }\end{array}$ & \\
\hline \multirow{5}{*}{7} & \multirow{5}{*}{$\begin{array}{l}\text { Provide vacant land for the establishment } \\
\text { of the public facilities }\end{array}$} & Availability of Worship Facilities & \multirow{5}{*}{2.08} \\
\hline & & Availability of open space / green outdoor & \\
\hline & & Availability of sports facilities and open field & \\
\hline & & Availability of trade and commerce facilities & \\
\hline & & $\begin{array}{l}\text { The accuracy of the developers promises a residential } \\
\text { facility }\end{array}$ & \\
\hline
\end{tabular}


4) Technical Characteristics Correlation: The correlations among the technical characteristics were obtained based on the interview conducted with the marketing manager of the company.

Based on the average levels of perceived condition, correlation matrix, and the relationship among the technical characteristics, a house of quality (HOQ) is constructed. The HOQ also concisely presents the priority level of the technical characteristics.

\section{IV.CONCLUSION}

This paper has measured the level of customers" satisfaction on the products and services offered by residence from PT Hati Prima Griya Elok using Importance Performance Analysis (IPA). It is found that the levels of satisfaction for the products and services are $78 \%$ and $76 \%$, respectively. This indicates that the residents are quite satisfied with products and services offered by the developer.

Based on the above satisfaction level, the priority for improvement has also been proposed for the items plotted in quadrant I and III. It is concluded that housing developers performance can be improved by providing a facility for prayer; taking actions to avoid flooding in the housing area, fixing damages in the surrounding area of the housing; providing facilities for commerce, sport, and outdoor activities; fixing the building damaged by the earthquake; constructing rainwater disposal facility; and fixing leaking in the houses.

This research also prioritizes action to be taken in order to improve the quality of services offered by the housing developers which are: (1) offer warranties for a specified period for prospective residents, (2) finish the houses on time, (3) assign an employee to come to the office during holidays and weekend to help queries form the customers, (4) provide a quick response to customers' needs, and (5) provide a better communication media with the customers.

Although this research does not consider the structure of houses in details, it has already assumed that the spatial requirements are already satisfied by the developer. Meanwhile, the effect of the cost variable is not being considered. The above limitations can be used as a starting point for future research aiming to expand the scope of this research.

\section{ACKNOWLEDGEMENTS}

This work was supported by Universitas Andalas under grant BOPTN Unand No. 06/UN.16/PL/API/2014.

\section{REFERENCES}

[1] P. J. Carling, "Return to community: Building support systems for people with psychiatric disabilities," Return to community: Building support systems for people with psychiatric disabilities., 1995. [Online]. Available:

http://ovidsp.ovid.com/ovidweb.cgi?T=JS\&PAGE=reference $\& \mathrm{D}=$ psyc3\&NEWS=N\&AN=1995-97329-000.

[2] I. Ahmed, "An overview of post-disaster permanent housing reconstruction in developing countries," Int. J. Disaster Resil. Built Environ., vol. 2, no. 2, pp. 148-164, 2011.

[3] BNPB, "Data dan Informasi Bencana Indonesia," Badan Nasional Penanggulangan Bencana. p. 1, 2017.
N. Zamri, F. Ahmad, A. H. Talib, and M. S. M. Ibrahim, “A survey on building safety after completing the construction process in Malaysia using statistical approach," Int. J. Adv. Sci. Eng. Inf. Technol., vol. 7, no. 2, pp. 387-398, 2017.

[5] Y. H. Chiang and B. S. Tang, "Submarines don't leak, why do buildings?' Building quality, technological impediment and organization of the building industry in Hong Kong," Habitat Int., vol. 27, no. 1, pp. 1-17, 2003.

[6] S. M. Baqutayan, "The Impact of Housing Issue on the Wellbeing of Middle-Income Group,” Mediterr. J. Soc. Sci., 2015.

[7] M. G. Holm, "Service quality and product quality in housing refurbishment," Int. J. Qual. Reliab. Manag., vol. 17, no. 4/5, pp. 527-540, 2000.

[8] J. Sommerville and J. McCosh, "Defects in new homes: an analysis of data on 1,696 new UK houses," Struct. Surv., vol. 24, no. 1, pp. 6-21, 2006.

[9] Q. Luo and P. T. James, "Influences on the buying behavior of purchasing commercial housing ousing in Nanning city of Guangxi province, China," J. Manag. Mark. Res., 2010.

[10] S. Yam, "The practice of corporate social responsibility by Malaysian developers," Prop. Manag., vol. 31, no. 1, pp. 76-91, 2013.

[11] O. C. Hansemark and M. Albinsson, "Customer satisfaction and retention : the experiences of individual employees Customer satisfaction and retention : the experiences of individual employees," in Managing Service Quality, 2004, pp. 40-57.

[12] P. Kotler, "Marketing Management, Millenium Edition," Mark. Manag., vol. 23, no. 6, pp. 188-193, 2000.

[13] P. Kotler and K. L. Keller, Marketing Management, 14th Edition, vol. 22 , no. 4. 2012.

[14] W. D. Hoyer, D. J. MacInnis, and R. Pieters, Consumer behavior. 2010.

[15] C. Fornell, M. D. Johnson, E. W. Anderson, J. Cha, and B. E. Bryant, "The American Customer Satisfaction Index: Nature, Purpose, and Findings," J. Mark., vol. 60, no. 4, p. 7, 1996.

[16] D. M. Szymanski and D. H. Henard, "Customer Satisfaction: A Meta-Analysis of the Empirical Evidence," J. Acad. Mark. Sci., vol. 29, no. 1, pp. 16-35, 2001.

[17] J. Wirtz, "Halo in customer satisfaction measures: The role of purpose of rating, number of attributes and customer involvement," Int. J. Serv. Ind. Manag., vol. 14, no. 1, pp. 96-119, 2003.

[18] F. Reichheld, R. G. Markey, and C. Hopton, "The loyalty effectthe relationship between loyalty and profits," European Business Journal, vol. 12, no. 3. pp. 134-139, 2000.

[19] J. K. Eskildsen and K. Kristensen, "Enhancing importance-performance analysis," Int. J. Product. Perform. Manag., vol. 55, no. 1, pp. 40-60, 2006.

[20] E. W. Anderson and V. Mittal, "Strengthening the SatisfactionProfit Chain,” J. Serv. Res., vol. 3, no. 2, pp. 107-120, 2000.

[21] Y. K. A.-A. Migdadi, "The impact of banking sector reform in developing economies on banking transactions security and quality: The case of Jordan," Int. J. Serv. Stand., vol. 9, no. 1, pp. 37-50, 2014.

[22] V. Mittal, W. T. Ross, and P. M. Baldasare, "The Asymmetric Impact of Negative and Positive Attribute-Level Performance on Overall Satisfaction and Repurchase Intentions," J. Mark., vol. 62, no. 1 , p. 33, 1998

[23] V. Mittal and J. M. Katrichis, "Distinctions between New and Loyal Customer," Mark. Res., no. Spring, p. 26, 2000.

[24] S. E. Sampson and M. J. Showalter, "The performanceimportance response function: Observations and implications," Serv. Ind. J., vol. 19, no. 3, pp. 1-25, 1999.

[25] M. E. González, G. Quesada, and A. T. Bahill, "Improving Product Design Using Quality Function Deployment: The School Furniture Case in Developing Countries," Qual. Eng., vol. 16, no. 1, pp. 45-56, 2003.

[26] I.B. Suryaningrat, "Implementation of QFD in Food Supply Chain Management: A Case of Processed Cassava Product in Indonesia," Int. J. Adv. Sci. Eng. Inf. Technol., vol. 6, no. 3, pp. 302-305, 2016.

[27] N. Slack, S. Chambers, and R. Johnston, Operations Management 2013.

[28] W. G. Zikmund, B. J. Babin, J. C. Carr, and M. Griffin, Business Research Methods. 2013. 


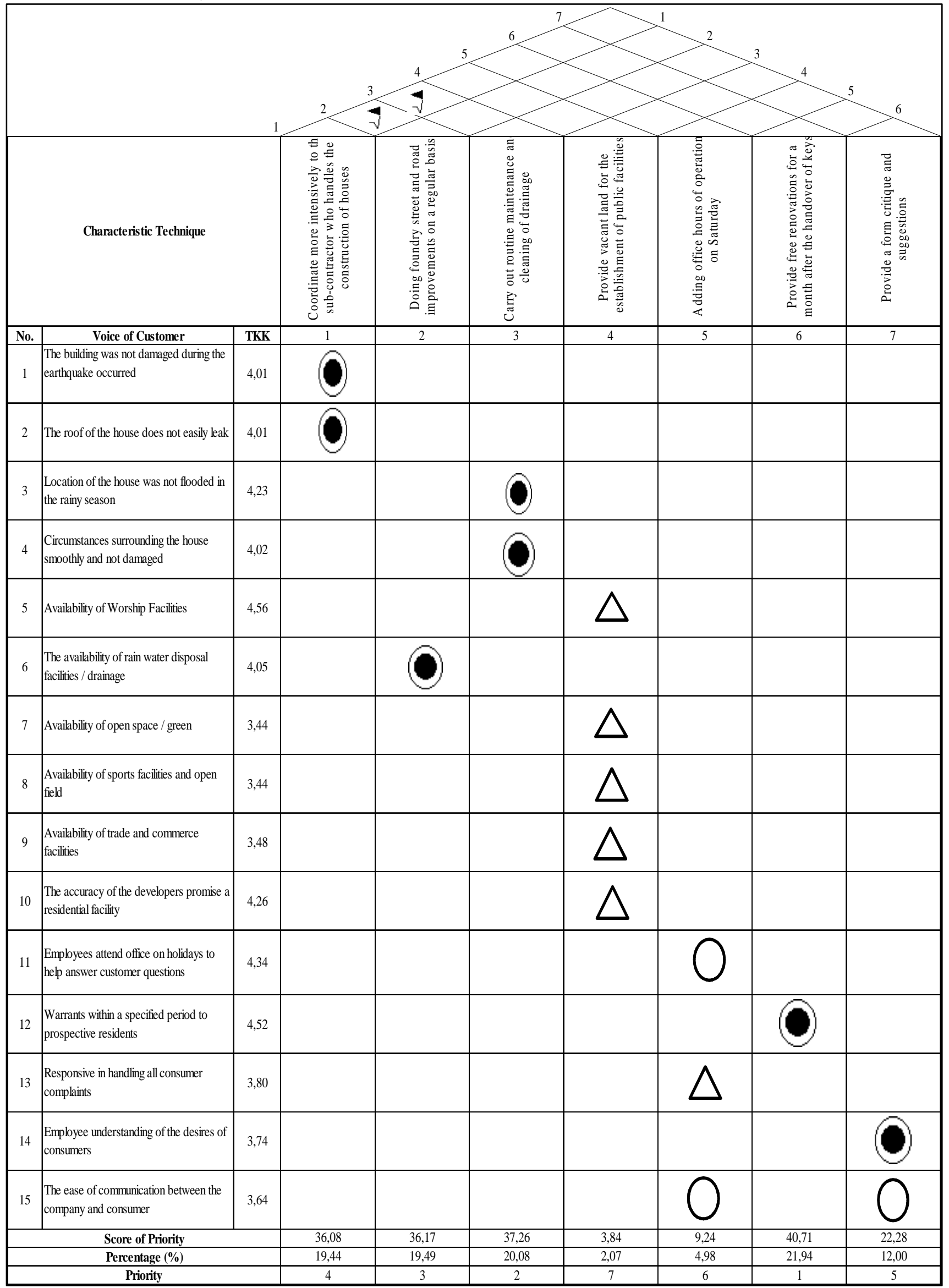

